Ssciendo Studia Anglica Posnaniensia 55s2 (2020): 465-494

doi: 10.2478/stap-2020-0023

\title{
IMPERIAL (S)KIN: THE ORTHOGRAPHY OF THE WAKE IN ESI EDUGYAN'S WASHINGTON BLACK
}

\author{
RŪTA ŠLAPKAUSKAITE ${ }^{1}$
}

\begin{abstract}
The publication of Esi Edugyan's Washington Black has placed the novel among other works of history and art, which recall the material and epistemic violence of institutional racism and the lasting trauma of its legacy. Thus by interlacing, within the context of black critical theory, Yogita Goyal's and Laura T. Murphy's examining of the neo-slave narrative with Christina Sharpe's conceptualization of the wake and Alexander G. Weheliye's notion of habeas viscus as critical frames for the discussion of racialized subjectivity, I consider how Edugyan's use of the conventions of Victorian adventure literature and the slave narrative rethinks the entanglements between the imperial commodification of life and the scientific agenda of natural history. Given how the narrative emphasizes the somatic register and its epidermal terms as a scene of meaning, I bring together Frantz Fanon's idea of epidermalization, Steven Connor's phenomenological reading of the skin, and Calvin L. Warren's reasoning about blackness in an attempt to highlight the metalepsis resulting from the novel's use of the hot air-balloon and the octopus as dermatropes that cast the empire as simultaneously a dysfunctional family and a scientific laboratory. Loaded into the skin as a master trope is the conceptual cross-over between consciousness and conscience, whose narrative performance in the novel nourishes the affective labour of its reader as an agent of memory.
\end{abstract}

Keywords: Skin; racialized subject; wake; slave narrative; epidermalization; dermatrope; habeas viscus.

A spark, though gleaming on the hovel's hearth, Which through the tyrant's gilded domes shall roar; A beacon in the darkness of the Earth;

A sun which, o'er the renovated scene, Shall dart like Truth where Falsehood yet has been.

Percy Bysshe Shelley, To a Balloon Laden with Knowledge

1 Department of English Philology, Institute of English, Classical, and Romance Studies, Vilnius University. ruta.slapkauskaite@ flf.vu.lt 


\section{Introduction}

Heir to the historical aftermath, contemporary literary culture does not sit easily in the folds of time. Its efforts to recover, revise, and rectify suggest that there is a lot of loose skin to account for in terms at once legal, legible, literal, and lateral. The body of work - both aesthetic and critical - that emerged in the last few decades and that addresses the legacies of the nineteenth century is notable for its political and ethical hold on the collective imagination and its struggle with global amnesia and complacency. In today's biopolitical climate, the imbricated meanings of racial oppression and the history of the Anthropocene prod us to reconsider the place of both in the economy of being, in the hope that this may solicit new ways of understanding the possibility of what Yogita Goyal calls "an ethical globalism" (Goyal 2019: 5). Framed as it is by the conventions of the slave narrative, on the one hand, and adventure romance, on the other, Canadian author Esi Edugyan's novel Washington Black (2018) offers an interesting example of "the moral technology of storytelling" (Goyal 2019: 32) that haunts the conceptual boroughs of both neo-slave and neo-Victorian discourse. It seems fitting, therefore, to briefly examine the conceptual tenets of the two avenues of thought to see how the novel casts in relief the concomitant actions of "ecological imperialism" (Crosby 1986) and what Christina Sharpe calls the "dysgraphia" of antiblackness, which "is pervasive as climate" (Sharpe 2016: 106).

The sub-chapters that precede the analysis of the novel assume the logic of exposition, shuttling across the discursive territories of the history of slavery and the phenomenology of race and skin. I begin by highlighting some of the key arguments in the analytic of race, which theorize the practices emerging out of "the politics of melanin" (Spillers 1987: 71) that organizes the field of black modernity in the wake of transatlantic slavery and the rise of neoliberal globalization. In doing so I take instruction from the work of Goyal, Sharpe, Laura T. Murphy, Hortense J. Spillers, Saidyia V. Hartman, and Alys Eve Weinbaum, who take issue with how "neo-liberal sentimental humanism" (Goyal 2019: 59) commodifies slavery as a discursive template to accommodate the stories of oppression from the Global South, conflating in the process the "hegemonic mandates of dominance" (Spillers 1987: 75) with "sentimental globalism" (Goyal 2019: 12) that sidelines slavery's "reproductive afterlife" (Weinbaum 2019: 1) in favour of the "neo-abolitionist" (Goyal 2019: 12) concern for affect and empathy as forms of transnational understanding. This overview

2 In her book In the Wake. On Blackness and Being (2016) Sharpe defines dysgraphia as "the inability of language to cohere around the bodies and the suffering of those who [sic] Black people who live and die in the wake and whose everyday acts insist Black life into the wake" (2016: 96). 
follows with a few considerations of how the "metahistoric and metacultural ramifications" (Heilmann \& Llewellyn 2010: 6) of contemporary engagement with Victorian culture problematize its narrative templates, enjoining on us a critical recognition of the material-semiotic crossovers between the nineteenth century's quest for knowledge and the imperial dominance over the enslaved world through "the scopophilic, disciplining, mutilating regime of science" (Heilmann \& Llewellyn 2010: 140). In this, I find urgency to mine the neoVictorian reimagining of slavery and emancipation in Washington Black as a productive reminder "of the complexities of terminologies, identities, and subjectivities" (Heilmann \& Llewellyn 2010: 29), which communicate the resonance of both "the slave episteme" (Weinbaum 2019: 1) and "the natural contract" (Serres 1995: 38) to contemporary readers. In thus locating Edugyan's novel in the tradition of neo-Victorianism and the neo-slave narrative, I also examine how its role in the Canadian literary context may potentiate new understandings of Canada's place in the history of slavery and contemporary racial politics. I close my critical overview by examining Alexander G. Weheliye's and Calvin L. Warren's conceptual arguments that link the analytic of race to theorizing about the skin as a source of selfhood.

2. Writing (in) the wake: Neo-Victorianism and the neo-slave narrative

The "new geographies of terror and containment" (Goyal 2019: 2), Goyal informs us in Runaway Genres, have turned slavery into a "site for the reinvention of form" (Goyal 2019: 1), with "at least three hundred narratives of contemporary slavery" published "since 1991" (Murphy 2019: 7). This has important implications for how we theorize the ambit and ethos of the slave narrative as a genre and how we think about race in the stronghold of what Weinbaum calls "biocapitalism", a mode of neoliberal governance derived from chattel slavery's practice of enforced black kinlessness and "reproductive extraction" (Weinbaum 2019: 7) that signals "the ascent of biotechnology, pharmaceuticals, genomics, and reprogenetics as primary areas of contemporary capitalist investment and expansion" (Weinbaum 2019: 5). Reminding us of how black motherhood "is outraged...[and] denied, at the very same time that it becomes the founding term of a human and social enactment" (Spillers 1987: 80; original emphasis), the material and epistemic spectrum of "the surrogacy/slavery nexus"3 (Weinbaum 2019: 8) in biocapitalism calls our attention to how contemporary racialized and

For Weinbaum, "the slavery/surrogacy nexus" explains how "the forms of reproductive labor and dispossession that exist in contemporary biocapitalism recall - even as the afterlife of reproductive slavery is disavowed - the reproductive extraction that enabled reproduction of human biological commodities in black women's wombs" (2019: 7). 
gendered precarity finds relief in the affordances of the slave narrative. As a number of scholars have shown (Wilson Starling 1988; Hembree 1991; Goyal 2019; Murphy 2019), with its roots stretching as far back as "the 1760s in the United States" (Murphy 2019: xix), the traditional form of this genre attempted to mobilize "the gravity of the story of captivity and the word "slavery" to provoke complacent citizens and nations to action" (Murphy 2019: 11) across the barrier of racial difference. While operating "at a charged intersection of celebrity humanitarianism, voyeurism, and advocacy", slave narratives made use of "an array of existing genres (including autobiography and ethnography, captivity narratives and the picaresque tale, the domestic novel and the spiritual confession)" (Goyal 2019: 16) to emphasize the link between literacy and freedom, thereby transforming the former slave into a putatively emancipated subject. In this, the legibility of the captive body served as a co-producer of meaning, reinforcing the veracity of the account already sanctioned by the white publisher. The limited purview of freedom made available to the newly emancipated, who were inaugurated into the double bind of what Hartman calls "burdened individuality" (Hartman 1997: 117), comprising freedom from slavery and lack of resources, sheds light on how the slave narrative continues to hang over the conceptual precipice of neoliberal subjectivity, whose stipulation of formal equality "is utterly enmeshed in the narrative of black subjection, given that slavery undergirded the rhetoric of the republic and equality defined so as to sanction subordination and segregation" (Hartman 1997: 116). As a template for the narrating of oppression and quest for freedom and a model for "transnational blackness" (Goyal 2019: 3), then, contemporary transformations of the genre, including "post-black satire" (Goyal 2019: 105) and new African diasporic fictions as well as the "new slave narratives" (Murphy 2019: 6), autobiographic accounts emanating from the Global South, recall the epistemic endurance of the historical scene of subjection, raising questions about what material impact rehearsal of familiar tropes may have on public consciousness and the political terrain of race relations.

Appeals to shared affective bonds with the reader, Goyal insists, lie at the heart of the "sentimental globalism" that characterizes the "neo-abolitionist thinking" in the accounts of contemporary slavery, which turn "to the past to dehistoricize contemporary atrocities as revivals of a superseded Atlantic past" (Goyal 2019: 12). Laura Murphy makes a similar point by examining how the new slave narratives employ the tradition as a "“soft weapon" in culture wars and political maneuvering" (Murphy 2019: 27) to boost their moral upshot as "neoliberal life narratives" (Murphy 2019: 6). Both critics highlight the moral ambivalence resulting from such universalizing of "the history that hurts" (Hartman 1997: 51) in an effort to reinscribe themselves into the neoliberal notion of selfhood without a deeper scrutiny of its complicity in the exploitation of the Global South. For 
while the affective labour performed by the accounts of contemporary slavery raises the stakes for the reader's responsibility in the hermeneutics of captivity, it also throws into crisis the "comparative literacy across past and present" (Goyal 2019: 9), which is crucial if the political praxis of this discourse is not to be compromised by the circuits of global capitalism in which it acts as "commodified currency" (Goyal 2019: 106).

Given how the use of the slave narrative today problematizes "the relation between past and present, between historical violence and continuing forms of inequality" (Goyal 2019: 5) as well as conceptions of resistance and agency, Christina Sharpe's conceptualization of the wake offers powerful insights into how the history of slavery continues to haunt postindustrial modernity. For Sharpe, as it is for Goyal, Murphy, and Weinbaum, among others, "[t]he history of capital is inextricable from the history of Atlantic chattel slavery" (Sharpe 2016: 5), subtending the contemporary forms of antiblackness which underscore "the orthography of the wake" (Sharpe 2016: 20-21) as a conceptual frame for thinking about the phenomenology of blackness. Defining the wake as simultaneously "the keeping watch with the dead, the path of a ship, a consequence of something, in the line of flight and/or sight, awakening, and consciousness", Sharpe renders the slave narrative conceivable as "wake work" (Sharpe 2016: 17-18) that bears witness to racial abuse as well as breaks through its conceptual tenets. Arguably, the neo-slave narrative fictions of Esi Edugyan, Colson Whitehead, and Paul Beatty, to name but a few, catalyze the power of the wake in a way that, unlike the new slave narratives of the Global South, cancel out any redemptive accounts of history and magnify the moral ambiguity involved in the technologies of neoliberal memory. The post-black satires of Whitehead and Beatty, as Goyal demonstrates, "elucidate contemporary rituals of race: deformations, contradictions, and grotesque and generative appropriations alike" (Goyal 2019: 116), so that the meaning of slavery becomes unsettled and the valency of race remains unresolved. While accounts of contemporary slavery tend to adopt the template of affective didacticism associated with the Middle Passage, the fictions of the new African diaspora and the neo-slave narratives "depart from expected ways of narrating migration and alienation" (Goyal 2019: 175), challenging the nineteenth-century's aesthetic imaginary as an adequate vehicle for black subjectivity. In Whitehead's novel The Underground Railroad, in particular, the historical metaphor is literalized in such a way that it disrupts any attempts to read the mobility of the fugitive slave in terms of escape and/or progress, "challeng[ing] the conceit of the rational apprehension of slavery today as well as a visceral identification with the slave ancestor" (Goyal 2019: 132). Yet this does not revoke the power of the novel's wake work; on the contrary, Whitehead's imaginative use of the conventions of adventure fiction, bildungsroman, and jeremiad in the frame of a neo-slave 
narrative marks out the genre's capacity to subvert the racist logic of the discourse of slavery and illuminate the abusive rationale that structures the social formations of today.

While insisting on thinking as a mode of care (Sharpe 2016: 5), the idea of the wake also clears a conceptual pathway through the reservoir of neo-Victorian writing, whose critical forays into the nineteenth century bring to surface the sedimental practices recovered from the flotsam and jetsam of what Steve Mentz calls "shipwreck's global modernity" (Mentz 2015: ix). I find Mentz's theorizing of "saltwater globalization" (Mentz 2015: xxi) useful in that it connects the contemporary transformations of the slave narrative to the engagements with the discourse of shipwreck, both of which emerge from the shared experience of maritime encounter, cultural dislocation, and ecological disaster. The wave of saltwater trouble on which contemporary neo-slave narratives ride amplifies Mentz's observation about how European maritime commerce created an ecological crisis by causing "the collapse of the native American population" and amassing "wealth and power in Europe after the plundering of Peru and Mexico and later the worldwide trade in African slaves" (Mentz 2015: xxviii). Similarly, recent ecocritical readings of Victorian literature (Amigoni 2010; Hall 2017; MacDuffie 2017) have offered a nuanced re-appreciation of the industrial modernity's contradictory concerns about economic growth and imperial expansion, on the one hand, and resource exhaustion, on the other. David Amigoni's analysis of the shared etymological ties between "culture" and "colony", in particular, highlights the mutual entanglements between nineteenthcentury science and literature and their investment in evolutionary discourse, which catapulted "into the field of culture a debate about the origin, making, substance and value of the bonds of sympathy, and, thereby, the forms of politics and collective belonging" (Amigoni 2010: 3). Coupled with Sharpe's notion of the wake and Mentz's reading of shipwreck modernity, this critique magnifies the ethical salience of rethinking what the French philosopher Michel Serres has called "the natural contract" (Serres 1995: 38) of our living in the coeval multiplicities of the world. Insofar as neo-Victorian fiction is preoccupied with "[1]oss, mourning and regeneration", usually in the metafictional form of a "re(dis)covery of a personal and/or collective history and the restitution of a family inheritance through the reconstruction of fragmented, fabricated, or repressed memories" (Heilman \& Llewellyn 2010: 34), it follows in the wake of the shipwreck that Alfred Crosby has tied to the biological expansion of Europe, submitting the labour of anamnesis to the test of the new epistemologies of salvage arising from the "changing ways of humanity and the natural world" (Mentz 2015: xxvi).

Refracted through the lens of neo-Victorianism and shipwreck modernity, Edugyan's novel heaves into view the conceptual links that align the neo-slave narrative poetics with the shipwreck as a "recognizable literary microgenre", 
namely their shared concern for "melodramatic presentation, epistemological crisis, and recuperative metaphysics" (Mentz 2015: xxx). Unlike the narrative arc of shipwreck, however, Washington Black does not offer a clear passage "from crisis to immersion to salvage" (Mentz 2015: xxxii). Indeed, it uses the figural dimension of "suspension in the oceanic" (Spillers 1987: 72) to inquire into the ways nineteenth-century racial and environmental epistemologies collapse into each other, producing both nature and the captive body as "a living laboratory" (Spillers 1987: 68), at the same time as they throw the humanist grammar of being into crisis. In doing so, the novel performs its wake work, not only reminding us of the Victorian obsession with race, which provided "a pseudo-scientific explanation for the entire history of Great Britain" and "a ready-made taxonomy for characterization" in literature (Brantlinger 2001: 151), but also calling our attention to the Canadian traffic in antiblackness, whose analysis, as Desmond Cole has shown most recently in The Skin We're In, tends to get submerged under the state-ship of official multiculturalism.

\section{Under surveillance: Canada and the slave episteme}

The cultural imaginary which mythologizes Canada as a place of refuge, rescue, and relief, takes at least some of its bearings from the historical experience of fugitive slaves, who made their escape from the United States through the social networks of the Underground Railroad. As Michael F. Hembree maintains, "Black migration from the United States to Canada during the antebellum years consisted of a modest but regular flow of settlers, punctuated by brief periods of mass migration" (Hembree 1991: 315). From the 1830s to the 1840s, Marion Wilson Starling adds, "between twenty and thirty thousand slaves had fled from the South" and in 1855, at the Fugitive Slaves Convention at Casenovia, Canada, "it was estimated that the number of fugitives then resident in Canada alone was fifty thousand" (Wilson Starling 1988: 39). However, as Hembree argues, both the abolitionist efforts to help the fugitives to settle in Canada and their Canadian reception were far from uncomplicated: soliciting funds often ran into American resistance against spending aid outside the United States, there were misconceptions about the fugitives' renunciation of American identity, and cases of the "deceitful behavior of agents entrusted with distributing the donations" (Hembree 1991: 319) were cropping up. Issues of financial accountability and moral integrity tied up with the social perception of raising donations as a form of begging, which, stemming from the tension between "abolitionists' lofty expectations and the fugitive slaves' daily struggles on the Canadian frontier" (Hembree 1991: 323), belied the emancipatory emphasis on black self-reliance. Given how the abolitionists "envisioned the black settlements in Canada as utopian communities, models of social and moral reform" (Hembree 1991: 323), 
it is hardly surprising that testimonies of racial prejudice, discrimination, and separatism in nineteenth-century Canadian society caused frustration to the antislavery movement. In fact, having lost its symbolic value after the Emancipation Proclamation of 1863 and the subsequent Reconstruction, Canada also ceased its status as a haven for fugitive slaves, with many blacks taking "the opportunity to return to the Unites States" (Hembree 1991: 327).

Simone Browne's incisive analysis of black history in Dark Matters. On the Surveillance of Blackness similarly throws into relief Canada's complicity in the "slave episteme" (Weinbaum 2019: 1) by reminding us how "the surveillance of black Atlantic mobilities was integral to the formation of the Canada-U.S. border" (Browne 2015: 69). In Browne's analysis transatlantic mobility correlates with shipwreck modernity, where the "cargo hold is slow-motion death" (Browne 2015: 48) that brings the "historical formation of surveillance" into alignment with "the historical formation of slavery" (Browne 2015: 50). As a discursive and material practice, Browne explains, surveillance subjected blackness to "a technology of social control" (Browne 2015: 16), turning it into "a key site through which surveillance [wa]s practiced, narrated, and enacted" (Browne 2015: 9), with advertisements for runaway slaves playing a crucial role in social discipline. In the Canadian context, a key moment of such "racializing surveillance" (Browne 2015: 16) was the composition of the Book of Negroes, which in Browne's perspective, was "the first government-issued document for state-regulated migration between United States and Canada that explicitly linked corporeal markers to the right to travel" (Browne 2015: 25). A historical record of black migration to Canada, among other things, the Book of Negroes puts us on notice to how the social procedures of tracking reified "boundaries, borders, and bodies along racial lines" (Browne 2015: 16), by subjecting racialized identities to the power of print to define not only their legal status, but also their humanity. "The travellers listed in the Book of Negroes", as Browne points out, "would later be recognized by many as United Empire Loyalists for their efforts as soldiers, support staff, and wage workers (cooks, blacksmiths, laundresses, nurses, spies, and other skilled laborers) with the British forces during the War of Independence" (Browne 2015: 70).

The Canadian author Lawrence Hill's novel The Book of Negroes illuminates this aporia of racism disguised as emancipation, by dramatizing in his neo-slave narrative the links between racialized surveillance and capitalist re/production, which structure his protagonist's quest for sovereignty both in the United States and Canada. The novel works toward a disrupting of the idea of Canada as a safe space for black subjects, suggesting, as Stephanie Yorke notes, that "it was politically expedient for slave narrators to present the British territory in this way, as they thereby further "proved" the potential success of Blacks who lived in a free state" (Yorke 2010: 141). To the extent that slave narratives feature Canada 
as a horizon of freedom, they tell us more about the ideological constraints in making public the truth about Canada as a society with slaves than they do about the material circumstances of living there as free black subjects. Unsurprisingly, genuine critical reflection on Canada's failure to do justice to its black residents emerged only in the work of contemporary Canadian scholars and artists, who, as Herb Wyile astutely argues in Speculative Fictions, "are much less inclined to construct patriotic narratives of the building of a nation and of a unitary Canadian character than to dramatize the exploitation, appropriation, and exclusion that such narratives of nation have often served to efface" (Wyile 2002: 7). Neo-slave narratives, like Hill's The Book of Negroes and Edugyan's Washington Black in Canada or Toni Morrison's Beloved and Whitehead's The Underground Railroad in the USA, bring to surface the mundane physical nature of daily racial oppression and violent abuse, exposing, at the same time, the ideological inconsistencies of the abolitionist movement, whose quest for emancipation usually did not extend to ideas about racial equality. Christine Duff's reading of Hill's novel, for example, is unequivocal about how it offers "a critique of the abolitionist movement in early nineteenth-century London" (Duff 2011: 243) and deals "a significant blow to any celebratory image of Canadian nationhood" (Duff 2011: 241) by laying bare its historical shortfalls: "While passage to Nova Scotia was provided, the commitment of land was not honoured, consigning the Black Loyalists to an extremely tenuous existence" (Duff 2011: 241). We may agree with Yorke's observation that the "slave narrative has outlived its apparent political function" (Yorke 2010: 129), but, as Goyal's and Murphy's research shows, the revisionary work of its contemporary forms - especially in the context of Black Lives Matter - demonstrates not only how this textual tradition serves as a corrective to the dominant vision of Canada "as a Canaan" (Yorke 2010: 141; original emphasis), but also how it "continues to inflect popular constructions of race" (Yorke 2010: 129).

\section{Epidermal thinking: Race, skin, being}

The question of race at the heart of both slave and neo-slave narratives has farreaching implications for the epistemological structures integral to Western biopolitical reason. The state of precarity in which many racialized communities live to this day suggests that the segregationist logic of the racial taxonomies heralded by eighteenth- and nineteenth-century sciences has firmly planted its roots in the ground of social relations, making the dispelling of the old ideas about race both a conceptual imperative and a moral necessity. It is in this context that the cultural critic W. J. T. Mitchell writes in Seeing through Race that "[r]ace is built with the bodies of myth as well as myths about bodies, and it is constituted as a reality that cannot be erased by fiat" (Mitchell 2012: 20). Rejecting the 
conceptual trap of treating race as a biological bracket, Mitchell attends to its social agency as discourse, whose praxis magnifies how our visual literacy is inscribed with the asymmetries of power. What causes a puncture in racial representations, in his reading, is that race operates not so much as an object of knowledge, but as "a medium and an iconic form", which is to say as "a framework for seeing through or...seeing as" (Mitchell 2012: 13; original emphasis). This means that race is not quite a social construct, but a lens that mediates, organizes, and inflects the dynamics of social relations, serving as "a vehicle for both fantasy and reality" (Mitchell 2012: 14; original emphasis). In other words, the racial medium generates templates of (mis)recognition, which braid together "objective and subjective capacities" (Mitchell 2012: 16) that test the epistemological and affective ground on which we arrange our perceptions, understandings, and imaginings.

Launching their thinking from the somatic field of the human, the theorists Alexander G. Weheliye and Calvin L. Warren further complicate references to race in the dominant discourse about bodies, subjectivities, and humanity, calling our attention to the ontological erasure of blackness in the procedural tenets of the Western intellectual tradition. For both critics, "the concept of the free black is a problem for thought" (Warren 2018: 51), re-anchoring blackness in "an integral structuring assemblage of the modern human" (Weheliye 2014: 32). Built into this reasoning is the understanding that the aftermath of slavery gave rise to the processes of racialization, which construe "race not as a biological or cultural classification but as a set of sociopolitical processes that discipline humanity into full humans, not-quite-humans, and nonhumans" (Weheliye 2014: 4). For Warren, this epistemic regime is symptomatic of the ontological crisis of blackness he calls the "metaphysical holocaust", that is "the systematic concealment, descent, and withholding of blackness through technologies of terror, violence, and abjection" (Warren 2018: 13). In this regard, "black being incarnates metaphysical nothing, the terror of metaphysics, in an antiblack world", functioning only in the service of "giv[ing] form to a terrifying formlessness" (Warren 2018: 5). The embodiment of ontological terror, a ““"phobogenic” object, provoking anxiety” (Fanon 2008 [1952]: 129), in Frantz Fanon's terms, blackness provides a conceptual premise for the dominant view of "the human as coterminous with the white liberal subject" (Weheliye 2014: 22) and, in Warren's analysis, is incompatible with black freedom because "it is the objectification, domination, and extermination of blacks that keep the metaphysical world intact" (Warren 2018: 6).

Though sharing Warren's view that black being operates in the service of "the ontological needs of the human" (Warren 2018: 45), Weheliye locates in the dynamics of racialization an aperture for black agency that affords the racialized body a "loophole of retreat" (Hartman 1997: 9), awakening it to the possibility of 
"itinerant acts of defiance" (Hartman 1997: 66) and "insurgent rationality" (Weinbaum 2019: 91). Borrowing Spillers's distinction between "body" and "flesh", ${ }_{4}$ Weheliye auditions his idea of habeas viscus, as a "modality of imagining the relational ontological totality of the human" (Weheliye 2014: 4), where the flesh "designates those dimensions of human life cleaved by the working together of depravation and deprivation" (Weheliye 2014: 39) that upset the normative templates of racialization by simultaneously acknowledging the history of subjection and imagining its palpable alternatives. At the crossroads of the body and the flesh, in this analysis, rest the structures of care that gather us into wake work and animate practices of liberation beyond the visual regiment of "racialized surveillance" (Browne 2015: 16).

The emphasis on the visual in this discussion, mobilizes the material dimension so as to recall Fanon's theorizing of the "epidermal racial schema" (Fanon 2008 [1952]: 92) and Paul Gilroy's "epidermal thinking" (Gilroy 2000: 46), which highlight how the visual perceptions of the skin deprive the black subject of "ontological resistance in the eyes of the white man" (Fanon 2008 [1952]: 90). The visual language of race compels us to consider not only how "dermo-politics" sets up "a historically specific system for making bodies meaningful by endowing with qualities of "color"" (Gilroy 2000: 46) and thus structures the practices of dehumanization, but also how it "ruptures the field of representation" (Warren 2018: 144), generating in its wake a "catachrestic fantasy", which, by voicing "the need to give form to that which is nothing" (Warren 2018: 150; original emphasis), calls into doubt narrative capacity to convey black experience. It is for this reason that Warren describes the slave narrative as "a thanatology" (Warren 2018: 40), foregrounding how the discursive apparatus - of both science and art - produces blackness as a "floating body" (Warren 2018: 56). Alongside Fanon's observations about how epidermalization (Fanon 2008 [1952]: xv) is constitutive of black subjectivity measured against the white body, I find it necessary to take into account the phenomenology of the skin because it permeates the figural dimension of Edugyan's novel, yielding a set of dermatropes, which materialize the conceptual collisions between "body" and "flesh" that conscript black being into the antiblack registers of a neo-Victorian setting. No less relevant is the significance skin was attributed in the Victorian cultural imaginary, where, as Pamela Gilbert avers in Victorian Skin, it "was a text to be read, a medium for the expression and interpretation of interiority" and thus "a substance integral to and having a creative role in the generation of the self" (Gilbert 2019: 1). The Victorian

For Spillers, "before the 'body' there is 'the flesh', that zero degree of social conceptualization that does not escape concealment under the brush of discourse, or the reflexes of iconography" (1987: 67). 
preoccupation with surface-self, where the skin was "both a location of perceptual consciousness and a signifying medium for the display of affect" (Gilbert 2019: 8 ), in turn, brought the advent of realist poetics, where the interpretation of the ambiguity of the body and the material world became "an ascendant mode of reading" (Gilbert 2019: 2). Edugyan's own interest in the discursive power of the skin resurfaces when we bear in mind that she claims to have conceived the idea of Washington Black through her encounter with the Tichborne case ${ }^{5}$, in which tattooed skin served as crucial evidence in determining fraud ${ }^{6}$. To better understand how Edugyan's neo-slave narrative invests the skin with the capacity to trope both man and the world, so that the material-semiotic relays between them expose the contradictions that structure our protocols of race and ecology, I will now briefly consider the conceptual arguments broached in Steven Connor's The Book of Skin.

Connor's historical overview of the phenomenology of the skin coheres around the conceptual ambiguity of its meanings. How the notion of the skin bears on the discourse of race, we are told, has a lot to do with the epistemic repertoire, in which the skin participates as a racial trope, a synecdoche for the body. Read in tandem with Weheliye's notion of the "racializing assemblage" (Weheliye 2014: 1) and Fanon's and Gilroy's theorizing of epidermalization, the skin's aggregatory power recalls the humoral theory, which used the word "complexion" to mean both skin and its colour as "a complex, a "weaving together" of elements of temperament or disposition" (Mitchell 2012: 17; original emphasis). In this view, by enveloping interiority with textural ligaments, the skin performed the work of both containment and mediation, nesting the human being not so much in the social divisions as in the cosmic order, which for a while provided the ultimate source of selfhood. The notion of the skin as an index of race, we learn, emerged with the Enlightenment's scientific interest in the skin as a thermodynamic engine and energy bank, inaugurating gradually a racial grammar of chromaticity, where social perceptions of blackness reduced

5 See https://www.theguardian.com/books/2018/oct/13/booker-shortlisted-authors-novelsinspiration. Accessed 17/07/2020.

6 Gilbert gives a succinct account of the case: "The Roger Tichborne trial was a cause célèbre, filled with melodrama, class tension, tragedy, and intrigue - and tattoos. Briefly, a butcher by the name of Arthur Orton, from Wagga Wagga, Australia, came to London in 1866 claiming to be Sir Roger Tichborne, the long-lost heir of a substantial fortune and family name. Roger, born in 1829, had been raised in France, and was lost at sea in 1854. Roger had been a thin man with light brown hair, and a French accent. (French was his first language.) Arthur was a very heavy man with dark hair who did not speak French. But Roger's bereaved mother grasped at the hope that her child was alive, and accepted the imposture. Some, perhaps in deference to Lady Tichborne, accepted him as well; others did not. Lady Tichborne died in 1868 , and the surviving family began to be restive. A trial to establish the claimant's identity took place over several months in 1871 and 1872" (2019: 318). 
subjectivity to its bodily surface. In this interpretive practice, the racialized subject becomes a sign, whose ultimate referential plane is their skin as a site of outward inscription. Underlying this axiology is the assumption that non-white skin has the function of a mark, which is often substantiated as an erasure of identity through epidermal incision and inscription, recalling the signs born by prisoners and slaves, whose skin gained social meaning in relation to their supervisors and owners. Yet, as Connor points out, even in the circumstances of hijacked or suspended sovereignty, the skin "can come to signify not just beauty and security, but value as such" (Connor 2004: 95), of which an important dimension pertains to its capacity to remember and narrate. In the context of race relations, in particular, the skin "means memory, means never being able or willing to forget" (Connor 2004: 86). To recall Sharpe's terms, it means living in "the orthography of the wake" (Sharpe 2016: 20-21).

What Connor's phenomenological account brings together are the politics and poetics of the skin, for the body's epidermal envelope is shown to have a creative and expressive power: "The skin figures. It is what we see and know of others and ourselves" (Connor 2004: 50-51). The tropological freight of dermatological imagery throws into relief the skin's agency as a social membrane, whose dialectical folds of inside/outside mediate the subject's multiple transactions and enmeshments with the world: "If the skin mediates the world by mingling with it, this may be because the world itself may be apprehended as a kind of flesh, or what biologists aptly call "tissue"' (Connor 2004: 29). This dynamic shows how the skin extends as a milieu, which operates as the ground that gives rise to and registers all other senses: it is "the global integral of these local area networks" (Connor 2004: 27) that constitute the affective range of the skin as an agent of sensuality, sensitivity, and sense-making, the somatic agency that palpably resonates in Weheliye's notion of habeas viscus (Weheliye 2014: 4). In other words, inasmuch as it is "the part of the body most likely to register emotions and states, such as shock, trauma, grief, fear, anxiety and shame", the skin is also "a thinking organ and a form of thought" (Wehelyie 2014: 99), which takes heart from the economy of reciprocity that propels it. In phenomenological terms, the skin materializes an aperture for our entanglements with the world, literally heaving into view the various ways in which we take note or lose sight of things, ignore or inscribe them with meaning, so that all figurations and disfigurations become epidermal extensions and prosthetic versions of our incorporated consciousness. As a "sign of our transformability" (Connor 2004: 32), therefore, the skin must be thought in conjunction with our theories of identity, where its ability to double on and fold in upon itself, to suffer assaults and abrasions as well as care and caress, call attention to the permeability of epidermal boundaries and the fluidity of identities which they seemingly hold together. 
Approaching the figuration of the skin in Washington Black in these terms promises to shed light on the enmeshments of the "politicized histories of race and empire" (Goyal 2019: 29) with the aesthetic forms of shipwreck modernity and its global saltwater ecology. It also casts the skin as a topos of biocapitalist transitions and transactions associated with technologies of surveillance and "the orthography of the wake" (Sharpe 2016: 20-21), suturing the globe with marks of uneasy continuity and rupture. As a trope too, its metaleptic ambivalence throws into view the ontological crisis of racialized subjectivity in the wake of lost networks of kinship: it conveys the historical embodiments of chattel slavery, scientific racism, antiblackness, somatic violence, and psychological abuse, but also bodily pleasures and practices of resistance through habeas viscus. Taking the hot air-balloon and the octopus as the novel's key dermatropes, i.e., tropes that derive from the skin's capacity to make and mediate sense, I examine the ways in which Edugyan employs the terms of the Victorian family to catalyze the narrative's mnemonic impulse in the service of rewiring our thinking about both race and nature. The resultant metalepsis, I hope to show, unspools the ethical ligatures of epidermalization and highlights the ecology of the wake as endemic to the neo-slave narrative's attempt to revise the racialized bonds that tie us to the material world.

\section{Flights of imagination: Imperial risks and racialized rewards}

The figurative language of the skin is the host of our attentiveness to the language of race in Washington Black. Framed as a series of memories, the narrative marshals the cognitive and affective resources of the wake to call our attention to how the historical record appropriates the racialized body to account for chattel slavery. As Sharpe points out, "Wakes are processes; through them we think about the dead and about our relations to them; they are rituals through which to enact grief and memory" (2016: 21). The novel's eponymous narrator and protagonist, now a free man "in possession of my own person" (Edugyan 2018: 13), begins his account by describing events following the death of his first master in Barbados and his own reaction to this news: "On that last evening I remember crouching on my bare heels in the stony dirt of Faith Plantation and pressing a palm flat against Big Kit's calf, feeling the heat of her skin baking up out of it, the strength and power of her, while the red sunlight settled in the cane all around us" (Edugyan 2018: 3). His verbal emphasis on the skin is unmistakable: to the child Wash, touching Big Kit's skin offers a modicum of solace he is otherwise denied as a parentless black slave. Inscribed with violence and abuse, Big Kit's flesh is conceived in parallel to the milieu surrounding them on Faith Plantation, immersing us in an understanding of how the enslaved bodies operate as "racializing assemblages" (Weheliye 2014: 1) aligned with the material effects of power. For a slave child, born into "natal 
alienation", whereby children were "wrested from their families and culturally and psychologically stripped of their capacity to have social relations anchored by genealogy" (Lawrance 2013: 674), tactility reconstitutes the lost kinship ties and brings into Wash's life a dimension of care that preserves his humanity. Seen through the lens of habeas viscus, the somatic tenacity of Wash's relationship with Big Kit recalibrates the possibility of agency, which erupts through affective bonds in shared space, work, meals, storytelling, and physical protection. Big Kit's epidermal proximity not only overrides the power of the skin mark branding Wash as a slave and property of the Wilde family, but also prefigures his later discovery that she was his mother (Edugyan 2018: 343).

The emotional ambiguity of Wash's relation to Big Kit exposes the degree to which the institution of slavery destroyed kinship ties: "I loved her and I feared her" (Edugyan 2018: 6). Spillers's observation is instructive here: "The destructive loss of the natural mother, whose biological/genetic relationship to the child remains unique and unambiguous, opens the enslaved young to social ambiguity and chaos" (Spillers 1987: 76). It ripples through Wash's memories of the eleven-year-old Émilie, whose "rounded belly, pressing against the starched fabric of her scullery whites" (Edugyan 2018: 63) links up with the images of other enslaved women leaving their "tender-skinned newborns down in the furrows" of the fields "to wail against the hot sun" (Edugyan 2018: 60). Though this is "a common-enough occurrence at Faith", Wash is nevertheless shocked into a realization that the father of Émilie's child "might be any man on the land, even the master himself" (Edugyan 2018: 63). The abjection of the slave's maternal body is magnified in Big Kit's outbursts of anger as a manifestation of her repressed love for her son. In an episode where Wash tells her to be mindful of using the machete for fear of clipping his leg, Big Kit knocks him out and cracks three of his ribs: "She took a heavy step forward; suddenly my breath was knocked from me; a vicious pain raged under my ribs" (Edugyan 2018: 89). The epidermal transaction of intimacy which follows the act of violence tells us the truth that the child Wash fails to grasp: "She was running a cold palm across my forehead, whispering. 'Oh my son,' I heard her say, over and over again. 'My son"” (Edugyan 2018: 90). This episode of maternal anguish, like the one where Big Kit plans to free herself and Wash by killing both, is interesting in several respects: on the one hand, it speaks of an intense affective bond of kinship that is unsustainable in a biopolitical regime where both the narrator and his mother are items of property of the plantation owner, and on the other, it manifests Big Kit's maternal subjectivity reclaimed through an act of repossessing her child in anger. Her use of force is part of the emotional ammunition of habeas viscus employed in the service of simultaneous self-assertion and self-denial. All the more devastating, then, is her ultimate separation from Wash when the new master of Faith Plantation, Erasmus Wilde, arrives to oversee slave labour. 
The curious combination of the Victorian sense of decorum and decadence encoded in the plantation owner's name links up with the narrator's portrayal of his sick flesh: "Under the burnished candlelight he looked as he had in the field - waxy and ill, the same colour as the rind of hard cheese that lay on the table before them. His flesh was slack, tired" (Edugyan 2018: 20). In contrast to his memory of the empathetic capaciousness of Big Kit's strong body, Wash's descriptions of Erasmus's skin highlight its capacity to expose the moral corruption it metaphorically embodies. The slave child fears that his master may be a vampire: "His slick white face gleamed, the clean white folds of his clothes shone impossibly bright, like a duppy, a ghost. I feared he must feed on blood to keep himself warm [...]" (Edugyan 2018: 5). The sickly image of the slave master reminds us of Connor's observations about how the skin functions as a filter of the material passages of time: "The skin is the vulnerable, unreliable boundary between inner and outer conditions and the proof of their frightening, fascinating intimate contiguity" (Connor 2004: 65). This intimacy of the shared tissue of slavery makes itself known through the images of scars, which record the material history of both the novel's blacks and whites. For example, Wash takes note of the "white earthworm scar" (Edugyan 2018: 114) on the face of Esther, a female slave, who "sometimes spoke as no slave should speak", her scar being "some testament to this" (Edugyan 2018: 115). Then again, Erasmus's abolitionist brother Christopher, known as Titch, also bears a scar, which runs "the length of both his cheeks", turning "bright red, like a line of blood" (Edugyan 2018: 57). Scarring, in Washington Black, together with images of the skin "cracked and scabbed with rash" (Edugyan 2018: 191), marked with "fleshy brown moles" (Edugyan 2018: 193), boils, and "large, dark, circular birthmarks" (Edugyan 2018: 306), and disfigured in shoulders "crudely severed off" (Edugyan 2018: 94), highlights the social work of the skin, whereby the violence suffered by the slaves haunts the body of the imperial masters. This seems to be particularly true in the case of the depressive Philip, the Wildes' cousin, who commits suicide in front of Wash: "The flesh of his face was folded viciously from the skull, like leather freshly cut" (Edugyan 2018: 121). The skin materializes as the milieu in which humans commingle with nature: the Wilde estate in Granbourne bears "ancient scars of weather and wars upon its façade" (Edugyan 2018: 329) whereas the slaves' skin gives off "the soft green smell of fresh-cut cane" (Edugyan 2018: 95) and the plantation bears "the white scars of harvest" (Edugyan 2018: 130). Indeed, the skin's susceptibility to wounding catches our attention most powerfully in the narrator's own physical vulnerability, to which he is exposed in the dramatic collisions between Erasmus and Titch, which culminates in Philip's suicide and Wash's escape from Faith Plantation. 
There is significance in how the skin's figuration in Washington Black catalyzes acts of both social inscription and subversion, through which the neoslave narrative aligns the protagonist's experience of racism with the scientific ethos of nineteenth-century industrial capitalism conveyed through its references to natural history and technological innovation within the bounds of the novel's neo-Victorian frame. In fact, the narrator's name seems to allude to Madison Washington, the protagonist of Frederick Douglass's fiction The Heroic Slave (2015 [1852]), simultaneously delivering a narrative indictment of slavery and racism and bringing into view the ambiguity of the novel's interest in "the act of (re)interpretation, (re)discovery and (re)vision concerning the Victorians" (Heilmann \& Llewellyn 2010: 4; original emphasis). For unlike Morrison's Beloved or Hill's The Book of Negroes, which examine the lasting horrors of the racialized space of the plantation as well as the perils of the Middle Passage, Edugyan's novel, like Whitehead's The Underground Railroad, also reminds us how the Victorian taste for adventure appropriated the picaresque spirit of the slave narratives (Wilson Starling 1988: 311) and, by recasting non-European characters as villains, subordinates, or rakes in juvenile adventure stories, like the ones published in the Victorian Boy's Own Paper, celebrated the values of risk, heroic masculinity, and English imperialism (see Lorimer in Lightman 1997; Miller 2012). In that respect, Wash's narrative reads no less like a tale of adventures than a critique of nineteenth-century race relations. In fact, his encounter with Titch mobilizes a series of risky escapades, which prime Wash for transformation in epidermal, social, and emotional terms. "And so", he observes, "began my strange second life" (Edugyan 2018: 47).

The narrative figure, around which the novel builds the ark of Titch and Wash's complicated relationship, is the Cloud-cutter, a hot air-balloon Titch constructs in an attempt to escape from his family duties and impress his naturalist father, who has opted for a life with a fellow explorer in the Canadian Arctic rather than share an English estate with his wife. One of a number of dermatropes, the novel's "incandescent orb in the sky" (Edugyan 2018: 207) evokes contradictory meanings: as a techno-somatic assemblage, it embodies the Victorians' "voracious appetite" (Lightman 1997: 187) for scientific knowledge, industrial development, and commercial success, reiterating the philosopher Peter Sloterdijk's note on how the figure of the orb is consonant with the "imperial revelation of power" (Sloterdijk 2014: 37), delivered through the Victorian social networks of professional and amateur scientists alike (see Lightman 1997). In its metonymic link to the Wildes' sugar plantation, the Cloudcutter serves as an industrial agent, highlighting the historical link between its own machinery and the original Spanish conception of the sugar plantation as ingenio, the engine of "an industry, in which not just sugar cane but human beings 
were the raw materials" (Ferguson 2003: 80). Although he refuses to compromise his abolitionist convictions by eating sugar, Titch asks his brother to lend him Wash and some other slaves for the Cloud-cutter, explaining that Wash is precisely the size he needs: "Ballast is key, you understand" (Edugyan 2018: 44).

Wash's depiction of the air-balloon captures the moral ambivalence of Titch's dream: "And there I saw the eerie, otherwordly orb of the inflated Cloud-cutter, the long cables holding it fast, the great monstrosity of it hovering there" (Edugyan 2018: 92). Arguably, what is most compelling about the Cloud-cutter is how it serves the double function of subjecting the slave's body to the dynamics of a "prosthetic network" (Ketabgian 2011: 19) comparable to the Victorian factory, on the one hand, and providing a means of escape, on the other. A material contraption based in the machine's prosthetic relations to the human body, for Wash, the Cloud-cutter becomes an antithesis of the slave ship, recalling the historian Richard Holmes's observation that in the Victorian era, the air-balloon turned into "an instrument of social justice, even moral redemption", offering a panoptic view that could lead "potentially to both planning and improvement" (Holmes 2014: 90). Where the slave ship operated simultaneously as a war machine, a mobile prison, and a factory (Youngquist 2011: 4), the airballoon evoked a pastoral dream, in which travelling "was silent, decorative, exclusive, and refreshingly unreliable: a means to mysterious adventure rather than a mode of mundane travel" (Holmes 2014: 52). The visual appeal of the balloon perspective transpires in the narrator's view of the island's body from the height of the mountain on which they construct the Cloud-cutter itself: "In the dusty light I saw the manicured fields of Faith Plantation, white lines cut into the earth. I stood shaken, confused by the incontestable beauty" (Edugyan 2018: 59). The price for "the aspirational metaphysics of ballooning" (Holmes 2014: 59), however, is exacted on Wash's own epidermal canvas, when his face is badly burned during an attempted ascent: "Then my face was afire, and I was lifted and thrown back in the shuddering milk-white flash of light, my head striking the ground" (Edugyan 2018: 85). To use Connor's terms, the narrator's disfigured skin "bears weight as its owner bears suffering" (Connor 2004: 62). The episode brings home the material continuity that undergirds the "haunting analogy between the silken skin of a balloon" (Holmes 2014: 3) and the human skin, whose charred cartography born by the face of a fugitive slave evokes the uneasy alliance between the Victorian ethos of errant masculinity, imperial security, and heroic action (see Freedgood 2000). In this respect, then, the figure of the air balloon may be read as an instance of metalepsis, an "abyss of representation" (Warren 2018: 151) which diagnoses the ontological uncertainty of Wash's life.

In light of Elaine Freedgood's analysis of balloon flights in the Victorian culture of risk, Titch's response to Wash's scarring gains a broader social significance as a sign of imperial epistemology: "Science has left its mark on you now, Wash. It has 
claimed you" (Edugyan 2018: 88). It also raises questions about Titch's capacity for empathy, not least because skin marking on Faith Plantation primarily signifies the "laboring material base" (MacKay 2002: 11) of bondage, thus calling into doubt Titch's abolitionist convictions. The ambiguity may have resulted from his own scarring and his fascination with risk-taking as an exercise in moral imagination: while using science to simultaneously distance himself from his family's complicity in slavery and connect himself to his absent father, Titch embraces scientific reason as providing access both to truth and "moral justification for the taking of the spoils both of industry and of empire" (Freedgood 2000: 94). What he does not see, however, is how the racial calculus subtending Victorian scientific inquiry hijacks black bodies as "a living laboratory" (Spillers 1987: 68) coextensive with the environment as a milieu in which observation and calculation become "weapons of pulverization and subjection" (Warren 2018: 111). As a panoptic device, the air-balloon also recalls the technology of surveillance, which used branding and runaway slave advertisements as means of tracking black mobility, grasping the power of epidermal thinking to generate what Browne calls "the epistemologies concerning sight at the site of the racial body" (Browne 2015: 26). Finally, as a means of escape, too, the Cloud-cutter compromises Wash's act of defiance because the decision to leave originates with Titch, who wants to save Wash from the punishment that awaits him for having seen cousin Philip commit suicide. In fact, Wash is ready to "accept whatever punishment awaits" (Edugyan 2018: 127). Their taking off is again conveyed in epidermal terms, with Wash's body seemingly merging with the environment and the gathering storm: "The air grew colder, crept in webs across my skin. All was shadow, red light, storm-fire and frenzy. And up we went into the eye of it, untouched, miraculous" (Edugyan 2018: 131). Titch helps Wash escape to freedom and even takes him to an abolitionist sexton in Norfolk, Virginia, thinking that the boy would opt to use the Underground Railroad and go to Upper Canada, but Wash chooses to accompany Titch to the Arctic to find his father. In all of this the white man's real motivations remain unclear. Exasperated by his father's neglect of his family, Titch decides to separate from Wash: "Your life is not my own. Do you understand me? I did not ask you to accompany me here" (Edugyan 2018: 215). Predictably, for Wash, this sudden departure offers another epidermal analogy, making him wonder how "even the risking of his own life w[as] worth being shed of me" (Edugyan 2018: 322).

The reward the narrator seemingly reaps from participating in Titch's scientific project has a material bearing on his racialized subjectivity, whose vulnerability is magnified in the image of the Cloud-cutter as a metaphor for "the generative cell of thought and being" (Sloterdijk 2014: 27). In phenomenological terms, insofar as the air-balloon is an aeronautic device, it functions as a master trope of thought, which congeals the novel's figurations of air and skin in an effort to deliver its catachrestic message. Connor's 
observation in The Matter of Air is instructive here: "Because air is the privileged matter of thought, the machinery of air is a way for thought to think its own workings, encouraged by the development of machines that produced, manipulated and projected across the spaces of the air" (Connor 2010: 99). The ideological tenor of the air-balloon, which appropriates the racialized body into its "prosthetic network" (Ketabgian 2011: 19), draws our attention to the conceptual ambivalence of Wash's subjectivity outside the bounds of Faith Plantation. How should we think about it: is the Cloud-cutter "a prosthetic attachment to the human body" (Ketabgian 2011: 17) or is Wash merely a prosthetic extension of the flying machine?

The scene of escape, conveyed through the image of the wrecked airballoon, takes a structurally highlighted position in the "orthography of the wake" (Sharpe 2016: 20-21) that constitutes Wash's narration. Pulling Wash into a shipwreck narrative, it puts a new onus on his quest for emancipation in what Mentz calls "an ecology of saltwater globalization" (2015: xxxi) and brings to surface the "dry truths" (Mentz 2015: 11) of epidermalization, whose logic binds Erasmus Wilde's hunt for Wash to the boy's search for freedom and family. At the center of this network of relations is the tropological agency of the skin figured as wake work in the metaleptic images of the Underground Railroad, as a system of underground tunnels disguised as graves (Edugyan 2018: 178-179), Wash's memories of the "dark, somber, beautiful" (Edugyan 2018: 212) face of Big Kit, and the medium of surveillance, epitomized in the advertisement penned by his tracker, John Willard (Edugyan 2018: 162). As a discursive mechanism of both subjection and subjectivity, the language of surveillance, which promises a reward of 1000 pounds to whoever finds Wash, is coeval with the disciplinary gaze of the captain of the ship that rescues him and Titch from the crash: "Are you a human creature?" (Edugyan 2018: 156) Though seemingly symptomatic of the "metaphysical holocaust" Warren (2018: 13) detects in Western thought, the question lodges in a cluster of affective intensities, which communicate the maritime encounter as a haptic boundary of racialized apprehension: "He reached out and touched the burnt half of my face, drawing his rough hand sharply back almost at once, as if scorched" (Edugyan 2018: 156). We are reminded here of Fanon's comment on the dissecting power of the white gaze: "I am overdetermined from the outside. I am a slave not to the "idea" others have of me, but to my appearance" (Fanon 2008 [1952]: 95). In contrast to the sense of emotional affinity secured through the tactile connection to Big Kit's body, the captain's touch evokes only "an impossible sadness" (Edugyan 2018: 156), which brings into view the epidermal terms that define the material and affective contingencies of Wash's life. His crisis of subjectivity is mirrored in the metaleptic logic of maritime commerce, which links the seafaring enterprise to the spoils of slavery: "Rum, molasses. Sugar. 
Goods from the Indies" (Edugyan 2018: 145). Re-anchoring Wash in the channels of slavery and black exploitation, the act of rescue recasts him as "a floating body" (Warren 2018: 56) forever searching for home.

If we accept Mitchell's idea of race as a visual medium (Mitchell 2012: 13), enmeshed in the material-semiotic asymmetries of power, then the narrative instances of epidermal thinking need to be considered in relation to Wash's own visual agency made manifest in his drawings. Part of his coping with the trauma of facial disfiguration and fleeing the plantation, the sketches recall Weheliye's notion of habeas viscus, highlighting the creative power of the flesh to overcome the strictures of racialization by reconfiguring the discursive potentialities of abused bodies. Even in Barbados, Wash's sketches of the different parts of the air-balloon begin as an act of disobedience, grounded in the sensorium of his flesh as a creative medium: "I felt something vital, some calming thing, go through me as I worked. Almost from the first it seemed a wonder to me, less an act of the fingers than of the eyes" (Edugyan 2018: 49). Similarly, on board the rescue ship he sets himself "the task of sketching everything on the ship, its berths and small cabins, the lower hold" (Edugyan 2018: 153) and later in Nova Scotia immerses himself in the drawing of marine life, "the anemones glowing pink as human flesh", "soft-shelled crabs" as well as "pansies or green sea urchins, large crabs, polyps magenta with toxins" (Edugyan 2018: 239). To the extent that Wash's sight and sketching work in conjunction with his grief, I am inclined to read his drawing as part of the novel's "orthography of the wake" (Sharpe 2016: 20-21), enabling us to take stock of the collisions between ink and skin in the hermeneutics of racial emancipation. The visual dimension of Wash's narrative speaks of the extent to which epidermalization functions as a lens mediating his perception of people and the environment. For example, when meeting Peter Haas, Wilde Senior's assistant, in the Arctic, his gaze elevates the man's facial topography to affective meaning: "His complexion was mottled with fleshy brown moles, and to the right of his high-arched nose stood a vicious, glistening boil that looked painful and full of poison" (Edugyan 2018: 193). His memories of the Arctic itself are bolstered by sensual wakefulness, reinforcing the idea of the environment as skin: "It had a colour, a taste - it wrapped itself around one like an unwelcome skin and began, ever so delicately, to squeeze" (Edugyan 2018: 195).

While extending a parallel between the epidermal envelope of Titch's pneumatic engineering and Wash's own drawing as "a dermatological dynamic of abrasions" (Connor 2004: 53), however, the Arctic adventure throws into crisis Wash's sense of kinlessness, exacerbating his emotional dependence on Titch as a source of family and friendship. Conceived in corporeal terms, the imperial world Wash and Titch navigate casts in relief both the inadequacy of scientific reason as a substitute for affective kinship and the asymmetry of power that 
inscribes their bodies with social meaning. For though both Titch and Wash seek proxy kin to overcome the sense of alienation generated by the institution of slavery, this relation of homology, which distils the epidermal register in the feats of artistry as techne, brings to surface Wash's gradual understanding that Titch too is complicit in epidermal thinking. At the end of the novel he accuses the white man of never having seen him as an equal: "You took me on because I was helpful in your political cause. Because I could aid in your experiments. Beyond that I was of no use to you, and so you abandoned me" (Edugyan 2018: 405). The fact that Titch tells Wash he treated him "as family" (Edugyan 2018: 405) highlights the extent to which "the epidermal racial schema" (Fanon 2008 [1952]: 92) contributes to the interiorization of the scientific imperatives that allow for the conflation of knowledge, commerce, and colonialism in Edugyan's neoVictorian world. In this, Wash and Titch emerge as the novel's alter egos scarred men, artists, and picaros - whose itchy feet seek to leave their mark on the skin of the earth through which they travel.

\section{Pricks of conscience: Material costs and moral conflicts}

Like Titch's technological constructions - the telescope (Edugyan 2018: 33), the Cloud-cutter (Edugyan 2018: 44), and the camera (Edugyan 2018: 401) - Wash's sketching participates in the nature/culture dialectic, which sets up the epistemological structures of a social order, where both the discourse of emancipation and of enslavement figure in the intellectual polemic spawned by Darwinism and its disciplinary offshoots. By employing the conventions of a "natural history novel" (Shuttleworth 1998: 253), Washington Black calls attention to the figural correlations between human abjection in slavery and the subjugation of nature in the protocols of Victorian science. Most evidently, by administering the relations between the social and biological axes in the novel, the empire is shown to graft over the maternal principle as a source of its biopolitical regiment that casts Wash as "a twisted black Englishman" (Edugyan 2018: 225). Unsurprisingly, even though he flees Faith Plantation, Wash does not free himself from the narrative of conquest and, in fact, by joining the efforts of the novel's gentlemen naturalists, becomes complicit in the imperial agenda that promotes European "planetary consciousness" (Pratt 1992: 29) and the empire as an adoptive mother.

It is worth remembering that the nineteenth century invented both nature, as a realm of scientific study and affective alliance, and childhood, as a socioeconomic and psychological category. Edugyan's interest in Victorian childhood, imperial parenting, and natural history seems congruent with her critical examination of the Victorian family as "a site of radical instability, ideological conflict and inconsistency" (Kohlke \& Gutleben 2011: 4) characteristic of neo- 
Victorian literary homes. In Washington Black, it is Titch's family, which, by virtue of its role as both a metonym and metaphor for imperial society, gives us access to the conceptual crossovers and continuities between "a quasigenealogical exploration of cultural legacies" and the "Darwinian inflected metaphors of origins, evolution, adaptation and inheritance" (Kohlke \& Guteleben 2011: 5). For example, Erasmus's violence finds its origin in his and Titch's torture of Philip as a child: "When he began to cry, we would strip him bare and leave him to walk naked home" (Edugyan 2018: 413). We trace an echo of this primal trauma in Titch's abandoning of Wash in the Arctic, with only some instruments and a "skin full of money" (Edugyan 2018: 226). The novel ties Titch's "ethical failures of care" (Kohlke \& Gutleben 2010: 135) to the dysfunctional nature of his family life: growing up with an emotionally repressed mother and largely absent father "with a broken apparatus in place of a heart" (Edugyan 2018: 206), in adulthood he struggles with sustaining the emotional bonds of human vulnerability. Within the bounds of the neo-slave narrative, this too partakes of the "orthography of the wake" (Sharpe 2016: 20-21), where Wash's memories of Big Kit are contrasted to the emotional distance in Titch's relationship with his parents, voiced in the sexton's observation in Virginia that "a good parent is as rare as snow in summer [...]" (Edugyan 2018: 169). Wash's reconnection with Big Kit in his dreams signals her death, whose iconography he cannot grasp: "A haze of pale light was furred around Kit's head, like a halo, and I could not make out her face" (Edugyan 2018: 211). Read in light of the social fractures in Titch's family life, her passing amplifies the crisis of kinship that imperialism instigated across the racial divide. In this, Big Kit literalizes the maternal body as a "textual enigma" (Weinbaum 2019: 95), whose interpretation follows in the wake of slavery.

In Eduguyan's novel, slavery's destruction of black families, made manifest in Wash's bond to Big Kit, is structurally homologous with the fractured relationship between Wilde Senior and his wife. Indeed, the old Wilde's lifestyle brings to light the aporia of Victorian science and domesticity, uncovering the degree to which both functioned in the service of imperialist ideology materialized through the conceptual and etymological links between human chattel and financial capital. While linking Faith Plantation to the maternal line of genealogical inheritance (Edugyan 2018: 173), Washington Black makes use of the Victorian trope of absent parenting, reaping dramatic yield from the image of "the stern father" (McKnight 2011: 3), embodied in Wilde Senior as a "model of the authoritative knower" (Davis in McKnight 2011: 6), who functions outside the social bonds of the bourgeois home. In this sense, the novel's difficult parents bring to light how the fractures in Victorian metropolitan families function as metonymic corollaries of disrupted familial ties in the space of colonial domesticity and racial dominance. As emotional alter egos, both Titch and Wash have absent fathers and "invisible" 
mothers. However, while Mrs. Wilde looms over a large manor house in Granbourne, the last time Wash sees Big Kit she is "maimed terribly, grown thinner, the hair at her temples silver as flies' wings" (Edugyan 2018: 100) so that he fails to recognize her, allowing us to see the body of the enslaved mother as a site for the inscription of denial, grief, and wake work. This memory ties in with Wash's meeting with Mrs. Wilde in Granbourne years later, when he goes to find Titch and instead is recommended the London Zoo, where, Titch's mother thinks, Wash "should feel quite at home" (Edugyan 2018: 335).

Coupled with the asymmetry in gender relations in Victorian society, Mrs. Wilde's remark calls attention to the correlations between the Victorian discourses on race and sexuality, whereby the novel communicates the conceptual parallels between Titch and Wash's relationship and the companionship of Wilde Senior and his research assistant Peter Haas. Arguably, Edugyan sees the emotional ties between gentlemen naturalists as coextensive with the homosocial nature of nineteenth-century discourse of natural history as a male-dominated kinship system. Eve Kosofsky Sedgwick has perceptively argued that "in any male-dominated society, there is a special relationship between male homosocial (including homosexuality) desire and the structures for maintaining and transmitting patriarchal power" (Kosofsky Sedgwick 1985: 25; original emphasis). When contrary to the rumours about his death, Titch and Wash find Wilde Senior in Arctic Canada, living in an igloo with Peter, Wash observes how the fellow scientist has replaced Titch's mother in his father's affections: "With Mister Peter he was affectionate and even tender. He touched him a great deal, even once tugging the greying hair at his nape softly" (Edugyan 2018: 200). Mortified though he is by the hint of his father's homosexuality, Titch does not realize that his own scientific work replicates homosocial ties and perpetuates the established cycle of imperial parenting. Having finally located Titch in Morocco, at the end of the novel, Wash finds that Titch has replaced him with a local boy, expressing a tenderness that hurts Wash: "a pain rose in my throat and I looked swiftly away" (Edugyan 2018: 395).

The irony of Wash's escape into this male-dominated social order, which promises him an alternative genealogy, is that he gains agency without gaining sovereignty. In Nova Scotia, for example, where he settles after leaving the Arctic, he toys with the idea of a new name, but "finding myself never able to answer to it, and uneasy in my skin besides, I dropped the ruse and became again Washington Black" (Edugyan 2018: 230). Contrary to the pleasures of freedom, life in Canada shows Wash how his complexion participates in the social transactions that define his livelihood: "But I found that the free, golden existence once described to me had been used up, crushed, drained to the skin by all who'd come before" (Edugyan 2018: 229). In fact, the experience of racism while working in the Shelburne docks makes him aware of how his skin functions as a 
medium of race relations: "My colour was already one burden; my burns made life unconscionable. One night I was held down in the alleyway behind a drinking establishment and beaten and urinated on by my laughing white colleagues, men with whom I daily worked" (Edugyan 2018: 231). This assault on his body and his "wrecked visage" (Edugyan 2018: 244) is coeval with his constant fear of capture and his eventual confrontation with Willard, who tracks him down long after the abolition of slavery and the death of Erasmus Wilde. The description of both the tracker's "tanned, calm" face with "a scar above his right ear" (Edugyan 2018: 287) and his attempt to murder Wash bears a distinct focus on the body as a site of meaning-making: "He fastened his hands at my throat, hot and callused, and I kicked out, my legs sprawling, my hands clenching at his own throat as I felt my breath choking off" (Edugyan 2018: 299). The shared figure of the scar sutures the two bodies in a "racializing assemblage" (Weheliye 2014:1), which uses the language of violence to mark out Wash as a nonhuman object of knowledge, an "[a]udacious nigger" (Edugyan 2018: 299). In this respect, then, Wash's use of a knife, which he thrusts into Willard's eye, becomes an act of defiance against the imperial organs of surveillance that define his subjectivity as "a stranger in my own skin" (Edugyan 2018: 233).

Read in light of Weheliye's theorizing of habeas viscus, the narrator's face-off with Willard pulls at the flesh as a source of black empowerment and links it to the creative agency associated with drawing marine life and falling in love. His visual immersion in the "tight explosions of green and yellow" in the "black waters" (Edugyan 2018: 232) of the docks attracts the attention of a fellow painter, a young woman with "dark, foxlike features, and vaguely narrowed eyes" (Edugyan 2018: 241), who turns out to be Tanna, the daughter of the respected marine biologist G. M. Goff. The consequences of this meeting, too, unfold in the economy of the wake. While awakening Wash to the pleasures of the flesh, this encounter also gradually makes him aware of how his experience of slavery, lodged in the body's mnemonic agency, compromises, in Mr. Goff's eyes, his role as Tanna's suitor. Recalling the work of the Victorian marine biologist Philip Henry Gosse in Newfoundland (see Edney in Hall 2017), the novel's Mr. Goff collects specimens in Nova Scotia and transports them to England, employing Wash for underwater explorations and visual illustrations of his research. As he joins the Goffs' efforts to collect "New World specimens for a small exhibition in London" (Edugyan 2018: 263), Wash, unbeknownst to himself, becomes part of a scientific apparatus that enlists the laws of nature to put into effect human power over the environment. A key figure in this activity is the octopus, whose capture reanimates the tropological significance of the skin in Wash's narrative of selfhood.

Insofar as the octopus is chromatically contiguous with the "incandescent orb" (Edugyan 2018: 207) of the Cloud-cutter, it is part of the narrative figuration of the skin, extending into the material canvas of the natural world, on which 
imperial science inscribes its authority. Given that the octopus sees through its skin (Godfrey-Smith 2017: 121), its metonymic link to nature correlates with the metaphorical link to Wash's racialized subjectivity, emphasizing how the epidermal condition of being is shared by humans and animals alike. The visual encounter between Wash and the octopus foregrounds a mirroring effect, where the octopus's blackness, navigational prowess, and use of ink offer a critical appraisal of Wash's own condition as a black man, former slave, and colonial artist. This is how the narrative highlights the affective reciprocity between the human and the cephalopod:

\footnotetext{
The octopus arranged itself in a smatter of algae, its body hanging blackly before me. When I came forward to touch it, it sent out a surge of dark ink. We paused, watching each other, the grey rag of ink hanging between us. Then it shot off through the water, stopping short to radiate like a cloth set afire, its arms unfurling and vibrating. There was something playful in the pause, as if it expected me to ink it back. I held my hands out towards it, gently; the creature hovered in the dark waters, stopping just inches away, its small, gelatinous eyes taking me in. Then it swam directly into my hands. (Edugyan 2018: 274)
}

Master of camouflage, the octopus alerts us to the narrative work of the skin in conceptualizing the dysphoric paradigm of imperial kinship. Its significance for Wash is twofold: on the one hand, it embodies his own capacity to morph, adapt, and escape from captivity; on the other, it remains an object of "a hierarchical vision of creation", wherein human dominance is conceived as "divinely ordained" (Ritvo 1987: 14). Kept alive in a bucket of water, the octopus is contrasted to the bones Wilde Senior collects in the Arctic and the dead specimens Mr. Goff classifies in his books. Wash marvels at the "dried starfish, large crabs, other sea fauna" and even "a tiny, brown, desiccated seahorse" (Edugyan 2018: 255), absentmindedly pinned in boxes in the Goffs' residence. His own wish, however, is to keep the octopus alive, for which purpose he experiments with plants in sea water, to create the material conditions necessary for the animal's survival. He also designs a large-scale tank to make possible the octopus's transportation to England, so that it could be exhibited as part of Mr. Goff's collection of marine exotica in the newly created Ocean House. In thinking about Wash's actions here, we do well to remind ourselves of Harriet Ritvo's note that in the Victorian era "Maintaining exotic animals in captivity was a compelling symbol of human power. Transporting them safely to England and figuring out how to keep them alive were triumphs of human skill and intelligence over the contrary dictates of nature; access to their native territories symbolized English power and prestige" (Ritvo 1987: 232). In this respect, then, on the novel's figural plane, the captive octopus lays bare the internal contradictions of Wash's racialized subjectivity: he is angry with Titch for having used him as "a rare thing" (Edugyan 2018: 405), but remains oblivious to how he 
subjects marine life to similar use. Unsurprisingly, perhaps, the end of the novel returns to this blind spot, reawakening Wash to the ghosts of the "epidermal racial schema" (Fanon 2008 [1952]: 92), on the hand, and Big Kit's motherly love, on the other. His decision to leave everything behind and find his mother's birthplace in Africa becomes symbolic of the endurance of wake work the novel performs through the ruses of neo-Victorian adventure romance. In this, Wash's wandering recalls Warren's critical observation that because Western ontometaphysics is inhospitable to black being, the black subject "moves and floats throughout the world, without a proper place or any geography that could be identified as home" (Warren 2018: 56).

For the gentlemen naturalists of Washington Black, the natural world, of which the octopus is a synecdoche, offers a fungible set of resources for "retrieving information" and certifying "a sweeping human claim to intellectual mastery of the natural world" (Ritvo 1987: 11-12). This human dominion over nature is shown to be coextensive with the sidelining of motherhood in the nineteenth-century institutions of slavery and imperial parenting. Serres's insight into how the earth, rather than being only a material means to human praxis, is, in fact, the "womb body" (Serres 2012: 46), the first habitat and source of our shelter and nourishment, allows us to connect Wash's sense of alienation in white society to the obliteration of racialized motherhood in the imperial labour of both slavery and natural history. Serres's analogy highlights the material-semiotic dimension of human subjectivity, tied to the maternal body of origin through the ligature of moral obligation that he calls "the natural contract of symbiosis and reciprocity", in which "our relationship to things would set aside mastery and possession in favor of admiring attention, reciprocity, contemplation, and respect" (Serres 1995: 38). In Washington Black, slavery's destruction of the institution of motherhood goes in synch with the instrumentalization of the earth on the sugar plantation, where the disavowal of "the natural contract" gives basis to the empire's market and moral economy. Arguably, it is because the imperial matrix displaces the original mater, both literally and metaphorically, that both Wash and Titch are doomed to forever navigate the imperial world figured as a dysfunctional family.

\section{Conclusion}

The tropological work of the skin in Washington Black unfolds a double conceptual premise. By marshalling its epidermal resources, the novel rethinks the category of race as a medium of seeing, calling for a renewed attention to the intellectual coordinates that sustain the "orthography of the wake" (Sharpe 2016: 20-21) in contemporary regimes of biocapitalism and antiblackness. At the juncture of neo-slave and neo-Victorian poetics emerges an ecocritical reflection 
on the material imprint of slavery, whose parameters exert pressure on expanding our categories of kinship as well as rescaling the historical responsibilities for the stigma of the Anthropocene. Both the air-balloon, as a "mediate matter of thought" (Connor 2010: 31), and the octopus, as "embodied cognition" (GodfreySmith 2017: 74), heave into view the conceptual power of complexion, which, by highlighting our material enmeshments with the world, suggest that biological distinctions and racial differences run skin-deep and blind us to the moral ligatures of "the natural contract" (Serres 1995: 38) that sustain sentient life. Instead of championing the "contemporary confidence in our technological, materialistic and financial supremacy.... at the root of our return to the Victorians" (Heilmann \& Llewellyn 2010: 244), Washington Black probes the cultural anxieties that spill over the moral frame of "the shipwreck of history" (Mentz 2015: xxiii), in which transnational global capitalism is continuous with, rather than disconnected from, transoceanic imperialism. Implicit in Edugyan's critique is also her concern for artistic ingenuity and agency, for which the air-balloon and octopus are eloquent tropes. The octopus, in particular, recalls Victor Hugo's comparison of the cephalopod to the artist, as explained by Margaret Cohen: "Like Hugo's octopus, the artist or writer undertaking the sublime search for new territories, becomes a figure with the potential to shed ethics, devoted to pure possibility" (Cohen 2013: 200). For Edugyan, however, the octopus becomes a metaleptic agent of the wake, offering a lens onto the act of writing, which sutures the scars of bodies and territories, history and memory, and fact and fiction, to turn out a narrative tissue that braids together science, consciousness, and conscience through bonds that surpass their etymological affinities, separate localities, and individual subjectivities.

\section{REFERENCES}

\section{PRIMARY SOURCES}

Cohen, Margaret. 2013. The novel and the sea. Princeton University Press. Douglass, Frederick. 2015 [1852]. The heroic slave. Yale University Press. Edugyan, Esi. 2018. Washington Black. Serpent's Tail.

Hill, Lawrence. 2007. The book of Negroes. HarperCollins.

Morrison, Toni. 1987. Beloved. London: Alfred Knopf.

Whitehead, Colson. 2016. The underground railroad. New York: Doubleday. 


\section{SECONDARY SOURCES}

Amigoni, David. 2010. Colonies, cults and evolution. Literature, science and culture in nineteenthcentury writing. Cambridge University Press. DOI: 10.1017/CBO9780511484711

Brantlinger, Patrick. 2001. Race and the Victorian novel. In Deirdre David (ed.), The Cambridge companion to the Victorian novel. Cambridge University Press. 149-168. DOI: 10.1017/CCOL0521641500.008

Browne, Simone. 2015. Dark matters. On the surveillance of blackness. Duke University Press.

Cole, Desmond. 2020. The skin we're in: A year of black resistance and power. Doubleday Canada.

Connor, Steven. 2004. The book of skin. Reaktion Books.

Connor, Steven. 2010. The matter of air. Science and art of the ethereal. Reaktion Books.

Crosby, Alfred W. 1986. Ecological imperialism. The biological expansion of Europe, 900-1900. Cambridge University Press. DOI: 10.1017/CBO9780511805554

Duff, Christine. 2011. Where literature fills the gaps: The Book of Negroes as a Canadian work of rememory. Studies in Canadian Literature 36(2). 237-255.

Fanon, Frantz. 2008 [1952]. Black skins, white masks. Grove Press

Ferguson, Niall. 2003. Empire. How Britain made the modern world. Penguin Books.

Freedgood, Elaine. 2000. Victorian writing about risk. Imagining a safe England in a dangerous world. Cambridge University Press. DOI: 10.1017/CBO9780511484797

Gilbert, K. Pamela. 2019. Victorian skin. Surface, self, history. Cornell University Press.

Gilroy, Paul. 2000. Against race. Imagining political culture beyond the color line. Belknap Press.

Godfrey-Smith, Peter. 2017. Other minds. The octopus and the evolution of intelligent life. HarperCollins.

Goyal, Yogita. 2019. Runaway genres. The global afterlives of slavery. New York University Press.

Hall, Dewey W. (ed.) 2017. Victorian ecocriticism. The politics of place and early environmental justice. Lexington Books.

Hartman, Saidiya V. 1997. Scenes of subjection. Terror, slavery, and self-making in nineteenthcentury America. Oxford University Press.

Heilmann, Ann \& Mark Llewellyn. 2010. Neo-Victorianism. The Victorians in the twenty-first century, 1999-2009. Palgrave.

Hembree, Michael F. 1991. The question of "begging": Fugitive slave relief in Canada, 1830-1865. Civil War History 37(4). 314-327. DOI: 10.1353/cwh.1991.0022

Holmes, Richard. 2014. Falling upwards. How we took to the air. William Collins.

Ketabgian, Tamara S. 2011. The lives of machines. The industrial imaginary in Victorian literature and culture. The University of Michigan Press. DOI: 10.3998/dcbooks. 9544598.0001 .001

Kohlke, Marie-Luise \& Christian Gutleben (eds.). 2010. Neo-Victorian tropes of trauma. The politics of bearing after-witness to nineteenth-century suffering. Rodopi.

Kohlke, Marie Luise \& Christian Gutleben (eds.). 2011. Neo-Victorian families. Gender, sexual and cultural politics. Rodopi.

Kosofsky Sedgwick, Eve. 1985. Between men. English literature and male homosocial desire. Columbia University Press.

Lawrance, Benjamin N. 2013. 'Your poor boy no father no mother': 'Orphans', alienation, and the perils of Atlantic child slave biography. Biography 36(4). 672-703.

Lightman, Bernard (ed.). 1997. Victorian science in context. University of Chicago Press.

MacDuffie, Allen. 2017. Victorian literature, energy, and the ecological imagination. Cambridge University Press. DOI: 10.1017/CBO9781107587533 
MacKay, John. 2002. "And hold the bondman still”: Biogeography and utopia in slave and serf narratives. Biography \& Geography 25(1). 110-129.

McKnight, Natalie (ed.) 2011. Fathers in Victorian fiction. Cambridge Scholars Publishing.

Mentz, Steve. 2015. Shipwreck modernity. Ecologies of globalization, 1550-1719. University of Minnesota Press.

Miller, John. 2012. Empire and the animal body: Violence, identity and ecology in Victorian adventure fiction. Anthem Press.

Mitchell, W. J. T. 2012. Seeing through race. Harvard University Press.

Murphy, Laura T. 2019. The new slave narrative. The battle over representations of contemporary slavery. Columbia University Press.

Pratt, Mary Louise. 1992. Imperial eyes. Travel writing and transculturation. Routledge.

Ritvo, Harriet. 1987. The animal estate. The English and other creatures in the Victorian age. Harvard University Press.

Serres, Michel. 1995. The natural contract. (Translated by Felicia McCarren.) The University of Chicago Press. DOI: 10.3998/mpub.9725

Serres, Michel. 2012. Biogea. (Translated by Randolph Burks.) University of Minnesota Press \& Univocal Publishing.

Sharpe, Christina. 2016. In the wake. On blackness and being. Duke University Press.

Shuttleworth, Sally. 1998. Natural history: The retro-Victorian novel. In Elinor S. Shaffer (ed.), The third culture: Literature and science. De Gruyter. 253-268. DOI: $10.1515 / 9783110882575.253$

Sloterdijk, Peter. 2014. Globes. Spheres vol. 2: Macrospherology. Semiotext(e).

Spillers, Hortense, J. 1987. Mama's baby, papa's maybe: An American grammar book. Diacritics 17(2). 64-81.

Warren, Calvin L. 2018. Ontological terror. Blackness, nihilism, and emancipation. Duke University Press.

Weheliye, Alexander G. 2014. Habeas viscus. Racializing assemblages, biopolitics, and black feminist theories of the human. Duke University Press.

Weinbaum, Alys Eve. 2019. The afterlife of reproductive slavery. Biocapitalism and black feminism's philosophy of history. Duke University Press.

Wilson Starling, Marion. 1988. The slave narrative. Its place in American history. Howard University Press.

Wyile, Herb. 2002. Speculative fictions. Contemporary Canadian novelists and the writing of history. McGill-Queen's University Press.

Yorke, Stephanie. 2010. The slave narrative tradition in Lawrence Hill's The book of Negroes. Studies in Canadian Literature 35(2). 129-145.

Youngquist, Paul. 2011. The mothership connection. Cultural Critique 77. 1-23. 